\title{
Emotional Intelligence, Psychological Well-Being, and Self-Control of Athletic and Non Athletic Postgraduates
}

\author{
Audronè Dumčienè
}

Lithuanian Sports University, Sporto g. 6, LT-44221 Kaunas, Lithuania, audrone.dumciene@lsu.lt

\begin{abstract}
The article presents differences in scores of components of emotional intelligence, psychological well-being, and self-control constructs' in terms of gender, athletic, non-athletic postgraduates, and significant correlations between some components' of the studied constructs. Only the scores of perception of emotion and using emotions were significantly higher for athletic than non-athletic. The article also presents models for predicting components' values of psychological well-being.
\end{abstract}

Keywords: emotional intelligence, psychological well-being, self-control, postgraduate students, achievements in sport.

\section{Introduction}

Students' emotional intelligence, psychological well-being, and self-control or willpower has been studied quite extensively. However, analogous characteristics of postgraduate students are examined much less frequently, although postgraduate studies are becoming increasingly popular.

Students' choices to study one or another program are determined by a complex of personal characteristics, competencies, among the most important of which, are emotional intelligence, self-control, psychological well-being, gender, and different achievement of athletic performance. 
Emotional intelligence is usually defined by two basic concepts: ability (Salovey \& Mayer, 1990) and traits (Bar-On, 1997). Emotional intelligence, according to Solovey and Mayer (1990), is a complex construct that encompasses the ability to understand, analyze, evaluate, express, manage one's own and others' emotions, and use them in one's life.

In this study, we support Solovey and Maye’s (Salovey \& Mayer, 1990; Mayer et al., 2016) approach to the emotional intelligence construct and will apply this concept of emotional intelligence based on abilities in our study.

Research has shown the relationships between emotional intelligence and educational achievement (Agnoli et al., 2012), and adapting, and changing situations (Gignac, 2010), to establish and maintain the necessary interpersonal relationships (Nozaki, 2015). A sufficiently high level of emotional intelligence helps to trigger and manage the necessary external emotions (Clark, 2016). Also, emotional intelligence helps maintain positive emotions and evokes a subjective sense of life satisfaction (Huang \& Lee, 2019).

The results of a study by Bahrololoum et al. (2012) showed a statistically significant relationship between emotional intelligence and goal-setting, self-confidence, and relaxation skills. Besides, emotions help a person focus their attention on the desired area. Individuals with higher estimates of emotional intelligence are characterized by complex and creative thinking (Murphy \& Janeke, 2009), and adaptive coping strategies for stress (Montvilaite \& Antinienè, 2019). Emotional intelligence is related to stress regulation and an athlete's motivation to play sports (Umbago-Jiménez et al., 2019).

The results of a study by Arribas-Galarraga et al. (2017) showed that emotional intelligence can act as a mediator between intrinsic motivation and achievement. Emotion regulation is a means by which an athlete creates and maintains positive emotional states that are beneficial to sporting performance (Kopp \& Jekauc, 2018). Studies show that emotional intelligence can enhance performance, job satisfaction, and prosocial behavior (Magrum et al., 2019).

Diener and Biswas-Diener (2008) indicate that a person's well-being reflects their subjective satisfaction with their life, emotional, and social aspects. Psychological well-being is a construct that includes a person's assessment of life satisfaction, a sense of satisfaction, assessments of various areas of life, and reactions to processes in those areas.

There are opinions (Pacesova et al., 2019) that a high level of personal well-being can predict good prospects for long-term stress management. According to Huppert (2009), psychological well-being is associated with good psychological health, prosocial behavior, and creative thinking. Psychological well-being is also associated with the harmony of life, according to Antonovsky (1987). It is not a stable derivative, and although it is formed in a person as an adult, it changes over time (Antonovsky, 1987, 218). Capone and Petrillo (2016) found that dissatisfaction with the quality of life has a significant association with depression and emotional exhaustion (burnout), and is influenced by the psychological-emotional environment of the workplace. Ahmadi et al. (2014) found, that emotional intelligence has a significant positive impact on psychological well-being. A positive influence of high 
emotional intelligence on physical and psychological well-being was found for postgraduates (Baqutayan et al., 2017).

Judge and Arora (2017), using correlation and step-wise regression analyses, found that emotional intelligence and psychological well-being are related and can be used to predict life satisfaction. Baumeister et al. (2007) believe that the concept of selfcontrol can be equated to a willpower concept, which is perceived as a form of energy. A distraction and loss of self-control weakens their willpower (Baumeister et al., 2007; Sela et al., 2017). Job et al. (2010) found that individuals who believed that willpower has limited resources achieved lower cognitive results in self-monitoring tasks. On the other hand, those who believed that willpower is unlimited achieved better results. These differences are explained by Job et al. (2010), who assert that, in performing complex tasks, people who believed willpower had limited resources were more sensitive to the psychological availability of resources. Duckworth et al. (2019) revealed links between self-control and academic achievement. Self-control is important for a person's behavior and well-being following Shoda et al. (1990) study results. Developed self-control has a significant impact on health and well-being in later life (Moffitt et al., 2011). Those with a higher level of self-control attain better academic achievement (Tangney et al., 2004).

De Ridder et al. (2012) revealed that individuals with a high level of self-control adapt better to a changing environment, which influences their accomplishments, well-being, and long lifespan. Subsequent research (Berkman et al., 2017) has revealed that selfcontrol is also related to personal values. It is known (Nielsen et al., 2019), that self-control is positively related to subjective well-being; moreover, this relation is a mediator in the use of self-control strategies.

The research question is whether the emotional intelligence, well-being, and selfcontrol of postgraduate students with high sports results differ from those of students who did not stand out more clearly in sports? The purpose of this study to find an answer to the question of how to differentiate between emotional intelligence, well-being, and self-control of athletic and non-athletic postgraduate students.

Tasks:

1. To find out the peculiarities of postgraduates' emotional intelligence, psychological well-being, and self-control from the aspect of gender.

2. To reveal the peculiarities of postgraduates' emotional intelligence, psychological well-being, and self-control from the aspect of being athletic/non-athletic.

3. To determine whether there are significant relationships between athletic/ non-athletic, gender, emotional intelligence, self-control components', and psychological well-being components', and which of these affect psychological well-being. 


\section{Methods and Materials}

\section{Study design and participants}

The study used the following three inventories and scales: Schutte Self-Report Inventory (SSRI) (Schutte et al., 1998), the Ryff Scale for Measuring Psychological Well-Being (RSMPWB) (Ryff, 1989), and the Tangney Short Self-Control Scale (Tangney et al., 2004).

The Schutte Self-Report Inventory is based on the Emotional Intelligence Ability Model (Salovey \& Mayer, 1990) and includes four components of emotional intelligence. These four components of emotional intelligence are a perception of emotions, managing one's emotions, managing other people's emotions, and using emotions (Mayer et al., 2016). This inventory has been chosen because it is one of the most commonly used instruments for assessing emotional intelligence (Laborde et al., 2016). The Schutte Self-Report Inventory contains 33 items that are rated according to a five-point Likert scale $(1=$ strongly disagree, 2 = disagree, $3=$ neutral, $4=$ agree, and $5=$ strongly agree). The Lithuanian version of the Self-Report Inventory description is confirmed by the reliability test and gives a reliability coefficient of .84 for the overall inventory (Malinauskas \& Sniras, 2010). The internal consistency of the Self-Report Inventory for this study was verified by calculating Cronbach's alpha coefficients of subscales: perception of emotions - .671, managing one's emotions - .733, managing other people's emotions - .653, and using emotions - .832.

The RSMPWB includes six subscales of psychological well-being: autonomy, environmental mastery, personal growth, positive relationships with others, purpose in life, and self-acceptance. The scale contains 54 items, 9 for each subscale. The RSMPWB is based on theoretical constructs of psychological well-being related to emotional health that include self-acceptance, positive relationships with others, autonomy, environment, mastery, life purpose, and personal development. The items should be evaluated on a 6-point Likert scale $(1=$ strongly disagree, 2 = disagree, 3 = slightly disagree, $4=$ slightly agree, $5=$ agree, and $6=$ strongly agree). A higher score means a higher level of psychological well-being. The Lithuanian version of the RSMPWB has a reported internal consistency of .84 (Malinauskas \& Dumciene, 2017). The internal consistency of the RSMPWB for this study was verified by calculating Cronbach's alpha coefficients of subscales: autonomy - .712, environmental mastery - .643, personal growth - .631, purpose in life - .621, and self-acceptance -.713 .

The Self-Control Scale (Tangney et al., 2004) was used to assess the self-control properties of research participants. The Self-Control Scale consists of 36 statements that the subject must rate on a five-point Likert scale $(1=$ strongly disagree, $2=$ disagree, $3=$ neutral, $4=$ agree, and $5=$ strongly agree). The Self-Control Scale includes five subscales of self-discipline, non-impulsive action, healthy habits, work ethic, and reliability. 
The Self-Control Scale (Tangley et al., 2004) was translated into Lithuanian by an English teacher. After that, another English teacher translated the scale back into English. The Lithuanian and English versions of the scale were checked by an English-speaking person fluent in English and Lithuanian. Both versions of the scale were submitted by 18 students fluent in Lithuanian and English, and they completed both versions of the scale. The recommendations of Aaronson et al. (2002) were followed for the adaptation of the scale. Correspondence between scale versions was estimated by calculating the Pearson correlation coefficient, which was $r=.78$. The internal consistency of the questionnaire for this study was checked by calculating Cronbach's alpha coefficients according to the subscales: self-discipline -.762 , non-impulsive action -.732 , healthy habits -.689 , work ethic -.759 , and reliability - .687 .

The Shapiro-Wilk test was used for the sample groups. Given the test results and the values of asymmetry and excess, the assumption of normality was partially satisfied (George \& Mallery, 2010). If the coefficients of excess and asymmetry are in the range of -2 to 2 , it is acceptable to consider the section as slightly away from normal. Due to differences between the number of athletes and non-athletes in postgraduates, the Mann-Whitney $\mathrm{U}$ test was chosen to check for statistical differences of the mean in comparison in this respect. Correlation and stepwise regression analyses were used to identify factors that significantly affect psychological well-being components.

\section{Participants}

The target group for the inquiry was students from postgraduate study programs. The participants' sample consisted of 65 postgraduates: 33 men and 32 women, including 14 with high achievements in sports (world champions, Olympic and European championship prize winners, Lithuanian championship prize winners). All the study participants participated in the study voluntarily, marking the statement in the first questionnaire: "I am participating in the study voluntarily. I have been provided with information on the anonymity and confidentiality of the investigation". The study was approved by the Committee for Social Sciences Research Ethics of the University (protocol No. SMTEK-44). The ethical recommendations were followed, which included legal requirements for researching in Lithuania.

\section{Results}

Data on the emotional intelligence components, psychological well-being, and selfcontrol of male and female students are presented in Table 1. 
Table 1

Estimates of Components of Emotional Intelligence, Psychological Well-Being, and Self-Control of Male and Female Students

\begin{tabular}{|c|c|c|c|c|c|c|c|}
\hline \multirow{2}{*}{ Scale } & \multirow{2}{*}{ Sub-scale } & \multicolumn{2}{|c|}{ Women $(n=32)$} & \multicolumn{2}{|c|}{ Men $(n=33)$} & \multirow{2}{*}{$t$} & \multirow{2}{*}{$p$} \\
\hline & & $\mathbf{M}$ & SD & $\mathbf{M}$ & SD & & \\
\hline \multirow{4}{*}{ 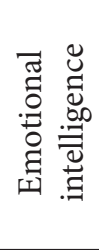 } & Perception of emotion & 2.80 & .256 & 3.44 & .196 & $11.46^{* * *}$ & .000 \\
\hline & Managing one's emotions & 2.83 & .284 & 3.27 & .264 & $6.45^{\star * *}$ & .000 \\
\hline & $\begin{array}{l}\text { Managing other people's } \\
\text { emotions }\end{array}$ & 3.37 & .327 & 3.51 & .252 & 1.96 & .054 \\
\hline & Using emotions & 2.93 & .537 & 2.78 & .398 & -1.28 & .206 \\
\hline \multirow{6}{*}{ 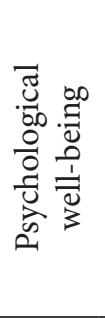 } & Autonomy & 4.30 & .373 & 4.64 & .694 & 2.43 & $.018^{\star}$ \\
\hline & Environmental mastery & 4.77 & .658 & 4.24 & .715 & -3.10 & $.003^{* *}$ \\
\hline & Positive relationships & 4.16 & .422 & 4.55 & .704 & 3.16 & $.002^{* *}$ \\
\hline & Purpose in life & 4.97 & .580 & 4.39 & .794 & -3.35 & $.001^{\star *}$ \\
\hline & Personal growth & 4.95 & .689 & 4.24 & .715 & -4.06 & $.000^{* * *}$ \\
\hline & Self-acceptance & 4.93 & .551 & 4.37 & .712 & -3.35 & $.001^{\star *}$ \\
\hline \multirow{5}{*}{ 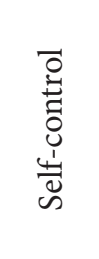 } & Self-discipline & 3.13 & .399 & 3.49 & .501 & 3.20 & $.002^{\star *}$ \\
\hline & Non-impulsive actions & 3.55 & .589 & 3.26 & .484 & -2.15 & $.035^{\star}$ \\
\hline & Healthy habits & 3.25 & .676 & 3.10 & .581 & .921 & .361 \\
\hline & Work ethic & 3.01 & .556 & 3.24 & .624 & 1.58 & .120 \\
\hline & Reliability & 2.87 & .482 & 3.26 & .663 & 2.70 & $.009^{\star *}$ \\
\hline
\end{tabular}

Notes. $(M, S D)-$ mean and standard deviation. ${ }^{\star}-\mathrm{p}<.05 ;^{\star \star}-\mathrm{p}<.01 ;{ }^{\star \star \star}-\mathrm{p}<.001$.

The results in Table 1 revealed that the estimates of the perception of emotion and managing one's emotions components of emotional intelligence for men were significantly higher than for women; however, using emotions score higher for women than men, although insignificantly. Women rated their environmental mastery, purpose in life, personal growth, and self-acceptance significantly higher than men. Men rated their autonomy and positive relationships significantly higher than women. Men rated self-control components, self-discipline and reliability higher than women, but women rated non-impulsive actions higher than men.

Data on the emotional intelligence, psychological well-being, and self-control components of athletic and non-athletic are presented in Table 2. 
Table 2

Estimates of Components of Emotional Intelligence, Psychological Well-Being, and Self-Control of Athletic and Non-Athletic

\begin{tabular}{|c|c|c|c|c|c|c|c|}
\hline \multirow[t]{2}{*}{ Scale } & \multirow[t]{2}{*}{ Sub-scale } & \multicolumn{2}{|c|}{$\begin{array}{l}\text { Athletic } \\
(n=14)\end{array}$} & \multicolumn{2}{|c|}{$\begin{array}{l}\text { Non-athletic } \\
\quad(n=51)\end{array}$} & \multirow[t]{2}{*}{$\mathbf{U}$} & \multirow[t]{2}{*}{$\mathbf{p}$} \\
\hline & & $\mathbf{M}$ & SD & $\mathbf{M}$ & SD & & \\
\hline \multirow{4}{*}{ 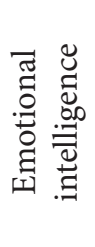 } & Perception of emotion & 3.40 & .384 & 3.04 & .365 & 167.00 & $.001^{\star *}$ \\
\hline & Managing one's emotions & 3.20 & .366 & 3.01 & .337 & 265.00 & .085 \\
\hline & $\begin{array}{l}\text { Managing other people's } \\
\text { emotions }\end{array}$ & 3.46 & .316 & 3.43 & .295 & 356.00 & .765 \\
\hline & Using emotions & 3.24 & .455 & 2.74 & .419 & 157.00 & .001 \\
\hline \multirow{6}{*}{ 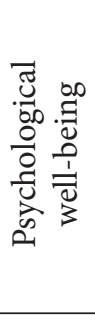 } & Autonomy & 4.17 & .512 & 4.56 & .574 & 215.50 & $.013^{*}$ \\
\hline & Environmental mastery & 4.66 & .746 & 4.46 & .729 & 337.50 & .559 \\
\hline & Positive relationships & 4.43 & .434 & 4.33 & .556 & 311.00 & .319 \\
\hline & Purpose in life & 4.80 & .840 & 4.64 & .727 & 329.50 & .479 \\
\hline & Personal growth & 4.61 & .692 & 4.58 & .814 & 365.50 & .882 \\
\hline & Self-acceptance & 4.62 & .708 & 4.65 & .695 & 335.50 & .539 \\
\hline \multirow{5}{*}{ 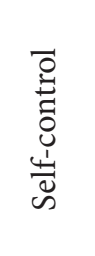 } & Self-discipline & 3.31 & .524 & 3.32 & .479 & 353.00 & .731 \\
\hline & Non-impulsive actions & 3.34 & .558 & 3.42 & .558 & 342.00 & .605 \\
\hline & Healthy habits & 3.19 & 652 & 3.17 & .629 & 373.50 & .981 \\
\hline & Work ethic & 3.08 & .570 & 3.14 & .612 & 361.00 & .826 \\
\hline & Reliability & 3.08 & .658 & 3.06 & .601 & 360.00 & .814 \\
\hline
\end{tabular}

Notes. $(M, S D)-$ mean and standard deviation; $U-$ Mann-Whitney criterion; ${ }^{*}-\mathrm{p}<.05$; $^{* *}-\mathrm{p}<.01$.

It was found that the scores of all components of emotional intelligence constructs of athletic were higher than for non-athletic, but only scores of the perception of emotion and using emotions were significantly higher.

Among scores of the components of psychological well-being, only the estimate of autonomy was significantly higher for non-athletic than for athletic.

The assessments of the components of the self-control construct did not reveal any significant differences between athletic and non-athletic.

Pearson correlation coefficients between emotional intelligence, self-control, gender, athletic/non-athletic, and psychological well-being components are shown in Table 3. 
Table 3

Pearson Correlation Coefficients between Emotional Intelligence, Self-Control, Gender, Athletic/Non-Athletic, and Psychological Well-Being Components

\begin{tabular}{|c|c|c|c|c|c|c|c|c|c|}
\hline \multirow[b]{2}{*}{ Scale } & \multirow[b]{2}{*}{ Sub-scale } & \multirow[b]{2}{*}{ Gender } & \multirow{2}{*}{$\begin{array}{c}\text { Athletic / } \\
\text { Non-athletic }\end{array}$} & \multicolumn{6}{|c|}{ Psychological well-being } \\
\hline & & & & 1 & 2 & 3 & 4 & 5 & 6 \\
\hline \multirow{3}{*}{ 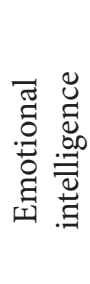 } & $\begin{array}{l}\text { Perception of } \\
\text { emotion }\end{array}$ & $-.822^{\star *}$ & -.382 & .050 & $.310^{*}$ & $-.337^{\star}$ & $-.478^{\star * *}$ & $-.339^{* *}$ & $-.255^{\star}$ \\
\hline & $\begin{array}{l}\text { Managing one's } \\
\text { emotions }\end{array}$ & $-.630^{\star *}$ & -.227 & .104 & .215 & -.222 & $-.262^{\star}$ & -.218 & -.240 \\
\hline & $\begin{array}{l}\text { Managing other } \\
\text { people's emotions }\end{array}$ & -.240 & -.041 & -.036 & .102 & $-.262^{\star}$ & -.098 & -.072 & -.059 \\
\hline \multirow{5}{*}{ 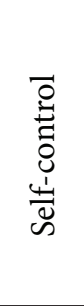 } & Self-discipline & $-.374^{\star *}$ & -.193 & .024 & .128 & -.053 & -.154 & -.169 & -.085 \\
\hline & $\begin{array}{l}\text { Non-impulsive } \\
\text { actions }\end{array}$ & $.261^{\star}$ & -.007 & -.196 & -.222 & .036 & .195 & .106 & .038 \\
\hline & Healthy habits & .115 & .054 & -.063 & -.170 & -.154 & -.106 & $.258^{\star}$ & .086 \\
\hline & Work ethics & -.195 & .067 & .084 & .034 & -.186 & -.199 & -.042 & -.089 \\
\hline & Reliability & $-.322^{\star *}$ & .160 & .150 & .162 & -.112 & -.177 & -.024 & -.170 \\
\hline \multicolumn{2}{|c|}{ Athletic/Non-athletic } & .101 & 1 & $.287^{\star}$ & -.080 & -.116 & -.015 & -.092 & .020 \\
\hline \multicolumn{2}{|c|}{ Gender } & 1 & .101 & $-.293^{\star}$ & $-.370^{\star *}$ & $.363^{\star *}$ & $.456^{* * *}$ & $.399^{\star \star \star}$ & $.407^{\star * *}$ \\
\hline
\end{tabular}

Notes. 1 - autonomy; 2 - environmental mastery; 3 - positive relationships; 4 - purpose in life; 5 - personal growth; 6 - self-acceptance. ${ }^{*}-\mathrm{p}<0.05 ;^{* *}-\mathrm{p}<0.01$; $^{* *}-\mathrm{p}<0.001$.

A more interesting result from the correlation analysis is that the coefficient is statistically insignificant in the correlation between gender and athletic/non-athletic. Of the 15 relationships between gender and the components of constructs of emotional intelligence, psychological well-being, and self-control, 11 are statistically significant. The only insignificant correlations are with managing other people's emotions, using emotion, healthy habits, and work ethics components.

Among the 66 relationships between the psychological well-being components and components of emotional intelligence, self-control, gender, and athletic/non-athletic, 15 were significant. The results of stepwise regression are presented in Table 4. 
Table 4

Stepwise Regression Analysis Results

\begin{tabular}{|c|c|c|c|c|c|c|c|}
\hline Model & $R$ & $R^{2}$ & $\begin{array}{l}\quad R^{2} \\
\text { adjusted }\end{array}$ & $F(d f)$ & 及 & $\begin{array}{c}\beta \\
\text { standar- } \\
\text { dized }\end{array}$ & $t$ \\
\hline \multicolumn{8}{|c|}{ Dependent variables: components of psychological well-being } \\
\hline \multicolumn{8}{|c|}{$\begin{array}{l}\text { Independent variables: components of emotional intelligence, self-control, gender, and athletes/ } \\
\text { non-athletes }\end{array}$} \\
\hline \multicolumn{8}{|c|}{ Dependent variable: autonomy } \\
\hline Model 1 & .446 & .199 & .173 & $7.686(64)^{\star \star}$ & & & \\
\hline Constant & & & & & 8.512 & & $7.01^{* * *}$ \\
\hline Gender & & & & & -.896 & -.778 & $3.896^{\star * *}$ \\
\hline Perception of emotion & & & & & -.864 & .293 & $2.955^{\star *}$ \\
\hline \multicolumn{8}{|c|}{ Dependent variable: Positive relationships } \\
\hline Model 2 & .370 & .137 & .123 & $9.993(64)^{\star \star}$ & & & \\
\hline Constant & & & & & 4.937 & & $25.55^{\star \star *}$ \\
\hline Gender & & & & & -.338 & -.370 & $-3.161^{\star *}$ \\
\hline \multicolumn{8}{|c|}{ Dependent variable: Environment mastery } \\
\hline Model 3 & .363 & .132 & .110 & $9.586(64)^{\star}$ & & & \\
\hline Constant & & & & & 3.716 & & $13.833^{* * *}$ \\
\hline Gender & & & & & .528 & .363 & $3.096^{\star *}$ \\
\hline \multicolumn{8}{|c|}{ Dependent variable: Personal growth } \\
\hline Model 4 & & .228 & .216 & $18.3(64)^{* \star *}$ & & & \\
\hline Constant & .478 & & & & 7.543 & & $10.95^{* * *}$ \\
\hline Perception of emotion & & & & & -.944 & -.478 & $4.317^{\star \star *}$ \\
\hline \multicolumn{8}{|c|}{ Dependent variable: Purpose in life } \\
\hline Model 5 & .468 & .219 & .194 & 8.683 & & & \\
\hline Constant & & & & $(64)^{\star * *}$ & 2.717 & & $14.008^{* * *}$ \\
\hline Gender & & & & & .518 & .347 & $3.056^{\star *}$ \\
\hline Using emotions & & & & & .417 & .263 & $2.312^{\star}$ \\
\hline \multicolumn{8}{|c|}{ Dependent variable: Self-acceptance } \\
\hline Model 6 & .407 & .165 & .152 & $12.487(63)^{\star * *}$ & & & \\
\hline Constant & & & & & 3.811 & & $15.304^{* * *}$ \\
\hline Gender & & & & & .559 & .407 & $3.534^{* * *}$ \\
\hline
\end{tabular}

Notes. $^{*}-\mathrm{p}<.05 ;{ }^{* *}-\mathrm{p}<.01 ;^{* * *}-\mathrm{p}<.001$.

The results of the stepwise regression analysis revealed that the factor of gender is included in the prediction models of psychological well-being components, except for the personal growth model. Interestingly, none of the self-control components and athletic/ non-athletic were included in the prediction models. 


\section{Discussions}

The means of the estimates were compared using the Student's t-distribution and Mann-Whitney $U$ test criteria to reveal differences in the estimates of the components of the constructs of emotional intelligence, psychological well-being, and self-control components in terms of gender and athletic/non-athletic students.

Our study revealed that postgraduate men rated significantly higher than women in their ability to perceive emotion and managing their own emotions. Our results do not contradict the statement of Wijekoon et al. (2017) that women have higher emotional intelligence than men. There are studies (Meshkat \& Nejati, 2017) that show that the overall level of emotional intelligence between men and women does not differ significantly, but differences have been found in the assessment of individual components. Other studies (Shahzad \& Bagum, 2012; Badawy \& Magdy, 2015; Nikbakhsh et al., 2014) also did not reveal significant differences in emotional intelligence across gender. High emotional intelligence is very important for educators because, as Naqvi et al. (2016) note, emotional intelligence has a positive influence on the effectiveness of teachers' professional activities. Our study found that athletic rate significantly higher than non-athletic, in the four components of emotional intelligence, perception of emotion, and using emotions. Emotional intelligence influences sport-related variables and factors beyond sport (Magrum et al., 2019). The correlations revealed in our study for the components studied reflected that too. Trigueros et al. (2019) believe that emotional intelligence has a positive effect on self-esteem and self-determination motivation in athletes. The results of a study by Arribas-Galarraga et al. (2017) show that emotional intelligence in athletes can act as a mediator between motivation and performance success. Singh and Sachdev (2020) found that individuals with high levels of emotional intelligence experience less stress. The estimates of the components of emotional intelligence obtained in our study do not contradict the results obtained by other researchers (Malinauskas \& Malinauskiene, 2018; Huang \& Lee, 2019; Brougthon, 2017; Sukys et al., 2019).

Interestingly distributed in our study are opinions of men and women looking at estimates of psychological well-being components scores. Women rated their environmental mastery, purpose in life, personal growth, and self-acceptance significantly higher than men. Men rated their autonomy and positive relationships significantly higher than women. The results of our study responded to a study that found that women's psychological well-being scores are higher than men's (Bingöl \& Batık, 2019). The scores of psychological well-being obtained in our study are not inconsistent with those of Pacesova et al. (2019). The psychological well-being scores obtained in this study confirm the results disclosed by earlier researchers (Malinauskas and Malinauskiene, 2018), although that study did not distinguish between male and female evaluations. Psychological well-being can be negatively influenced by negative emotions (Liu et al., 2019). However, it can also be influenced by the individual because, as indicated Singh and Sharma (2018), self-regulation 
abilities have a positive association with psychological well-being and its components. Good life skills can positively influence educators' psychological well-being (Kasapoglu \& Didin, 2019). This is confirmed by the significant correlations between the components of psychological well-being, self-control, and emotional intelligence revealed in our study. As Kurt and Demirbolat (2019) point out, a high level of psychological well-being has a positive effect on educators' job satisfaction. In our study, in the evaluations of athletic and non-athletic for psychological well-being components, only autonomy estimates for non-athletic were significantly higher than for athletic.

Our study found that significantly higher scores were found for women for the components of the self-control construct and non-impulsive actions, and for men the scores for the components self-discipline and reliability were significantly higher. The assessments of the components of the self-control construct did not reveal any significant differences between athletic and non-athletic. As Boat and Cooper (2019) point out, higher levels of self-control are associated with higher levels of exercise, but depleted self-control reduces operational efficiency and perseverance in other activities that require self-control efforts. Higher levels of self-control are associated with higher academic achievement, better interpersonal relationships, and better well-being (Cheung et al., 2014; Hofmann et al, 2014). However, Gillebaart and De Ridder (2015) argue that self-control simply cannot rely on inhibition efforts alone, as that would lead people prone to self-control towards exhaustion, fatigue, lack of attention, and/or lack of motivation.

By assessing the relationships between the components of emotional intelligence, psychological well-being, self-control constructs, and gender revealed a variety of statistically significant relationships. The results of our correlation analysis confirm the observations of other researchers (Nielsen et al., 2019; Montvilaite \& Antiniené, 2019; Baqutayan et al., 2017).

In stepwise regression analyses, prediction models were constructed in the first or second steps. The results of the stepwise regression analysis revealed that the factor of gender is included in the prediction models of psychological well-being components, except for the personal growth model. Interestingly, none of the self-control components and athletic achievement factors (athletic/non-athletic) were included in the prediction models.

\section{Conclusions}

Male and female postgraduates evaluate significantly differently for many components of the constructs of emotional intelligence, psychological well-being, and self-control.

In terms of different athletic performances (athletic/non-athletic), both men and women had significantly different scores for the components of the constructs of emotional intelligence, psychological well-being, and self-control - a much smaller number of cases 
than in terms of gender. Thus, in terms of athletic/non-athletic, men's and women's assessments differed less frequently than in terms of gender.

Gender is significantly associated with components of emotional intelligence, psychological well-being, and self-control, except for healthy habits, work ethics, managing one's emotions, and using emotion. Athletic/non-athletic are significantly associated only with the autonomy, perception of emotion, and usage of emotion, but are not significantly related to gender.

Only emotional intelligence components and gender were significant for the prediction models of psychological well-being components.

\section{Information about funding and acknowledgements}

No funding was received for the study. The author expresses gratitude to all the postgraduate students who participated in the study.

\section{References}

Agnoli, S., Mancini, G., Pozzoli, T., Baldaro, B., Russo, P. M., \& Surcinelli, P. (2012). The interaction between emotional intelligence and cognitive ability in predicting scholastic performance in school-aged children. Personality and Individual Differences, 53(5), 660-665. https://doi. org/f36qfc

Ahmadi, S. A. A., Azar, H. K., Sarchoghaei, M. N., \& Nagahi, M. (2014). Relationship between emotional intelligence and psychological well-being. International Journal of Research in Organizational Behavior and Human Resource Management, 2(1), 123-144.

Antonovsky, A. (1987) Unraveling the mystery of health. San Francisco (CA): Jossey-Bass Publishers. Aaronson, N., Alonso, J., Burnam, A., Lohr, K. N., Patrick, D. L., Perrin, E., \& Stein, R. E. (2002). Assessing health status and quality-of-life instruments: attributes and review criteria. Quality Life Research, 11(3), 193-205.

Arribas-Galarraga, S., Saies, E., Cecchini, J. A., Arruza, J. A., \& Luis-De-Cos, I. (2017). The relationship between emotional intelligence, self-determined motivation and performance in canoeists. Journal of Human Sport and Exercise, 12(3). doi:10.14198/jhse.2017.123.07

Badawy, T. A. E., \& Magdy, M. M. (2015). Assessing the impact of emotional intelligence on job satisfaction: An empirical study on faculty members with respect to gender and age. International Business Research, 8(3), 67-78. doi:10.5539/ibr.v8n3p67

Bahrololoum, H., Hassani, A., Bandeli, M. R., \& Akbari, A. (2012). The relationship between the emotional intelligence and mental skills in Iranian elite male volleyball players. International Journal of Academic Research in Business and Social Sciences, 2(7), 123-130. 
Baqutayan, S. M. S., Ghafar, S. W. A., \& Gul, M. (2017). The relationship between stress and emotional intelligence among postgraduate students: The case study at Perdana school of science, technology and innovation policy (STI Policy), University Technology Malaysia. International Journal Behavioral Science, 11(2), 74-81.

Baumeister, R. F., Vohs, K. D., \& Tice, D. M. (2007). The strength model of self-control. Current Directions in Psychological Science, 16(6), 351-355. doi:10.1111/j.1467-8721.2007.00534.x.

Berkman, E. T., Hutcherson, C. A., Livingston, J. L., Kahn, L. E., \& Inzlicht, M. (2017). Selfcontrol as a value-based choice. Current Directions in Psychological Science, 26(5), 422-428. doi:10.1177/0963721417704394

Bingöl, T. Y., \& Batık, M. V. (2019). Unconditional self-acceptance and perfectionistic cognitions as predictors of psychological well-being. Journal of Education and Training Studies, 7(1), 67-75. doi:10.11114/jets.v7i1.3712

Broughton, N. (2017). Evaluation of emotional intelligence. International Journal of Business and Social Science, 8(6), 6-15.

Boat, R., \& Cooper, S. B. (2019). Self-control and exercise: A review of the bi-directional relationship. Brain Plasticity, 5(1), 97-104. doi:10.3233/BPL-190082

Capone, V., \& Petrillo, G. (2016). Teachers' perceptions of fairness, well-being and burnout: A contribution to the validation of the organizational justice index by hoy and tarter, International Journal of Educational Management, 30(6), 864-880. http://dx.doi.org/10.1108/ IJEM-02-2015-0013

Clark, R. (2016). Intelligence Analysis: A Target-Centric Approach. London: CQ Press.

Cheung, T. T., Gillebaart, M., Kroese, F., \& De Ridder, D. T. D. (2014). Why are people with high self-control happier? The effect of trait self-control on happiness as mediated by regulatory focus. Frontiers in Psychology, 5, article 722, 1-6. doi:10.3389/ fpsyg.2014.00722

De Ridder, D. T. D., Lensvelt-Mulders, G., Finkenauer, C., Stok, F. M., \& Baumeister, R. F. (2012). Taking stock of self-control: a meta-analysis of how trait self-control relates to a wide range of behaviors. Personality and Social Psychology Review, 16(1), 76-99. doi:10.1177/1088868311418749

Deci, E. L., \& Ryan, R. M. (2000). The "what" and "why" of goal pursuits: Human needs and the self-determination of behaviour. Psychological Inquiry, 11(4), 227-268.

Deci, R. L., Koestner, R., \& Ryan, R. M. (2001). Extrinsic rewards and intrinsic motivation in education: Reconsidered once again. Review of Educational Research, 71(1), 1-27.

Diener, E., Oishi, S., \& Lucas, R. E. (2003). Personality, culture, and subjective well-being: Emotional and cognitive evaluations of life. Annual Review of Psychology, 54(1), 403-425. https://doi.org/10.1146/anurevpsych.54.101601.145056

Duckworth, A. L., Taxer, J. L., Eskreis-Winkler, L, Galla, B. M., \& Gross, J. J. (2019). Selfcontrol and academic achievement. Annual review of psychology, 70(5), 373-399. https://doi. org/10.1146/annurev-psych-010418-103230

Judge, J., \& Arora, A. K. (2017). A study of impact of emotional intelligence and psychological wellbeing on life satisfaction among adolescents. International Journal of Advanced Educational Research, 2(6), 301-305. 
George, D. \& Mallery, P. (2010) SPSS for Windows step by step: A simple guide and reference 17.0 update (10th ed.)., Boston: Allyn \& Bacon. https://lib.ugent.be/catalog/rug01:001424067

Gignac, G. E. (2010). On a nomenclature for emotional intelligence research. Industrial and Organizational Psychology, 3(2), 131-135.

Gilar-Corbi, R., Pozo-Rico, T., Sanchez, B., \& Castejon, J. L. (2019). Can emotional intelligence be improved? A randomized experimental study of a business-oriented EI training program for senior managers. PLoS ONE, 14(10): e0224254. https:// doi.org/10.1371/journal.pone.0224254

Gillebaart, M., \& De Ridder, T. D. (2015). Effortless self-control: a novel perspective on response conflict strategies in trait self-control. Social and Personality Psychology Compass, 9(2), 88-99. doi:10.1111/spc3.12160

Hofmann, W., Luhmann, M., Fisher, R. R., Vohs, K. D., \& Baumeister, R. F. (2014). Yes, but are they happy? Effects of trait self-control on affective wellbeing and life satisfaction. Journal of Personality, 82(4), 265-277. doi:10.1111/jopy.12050

Huang, N., \& Lee, H. (2019). Ability emotional intelligence and life satisfaction: Humor style as a mediator. Social Behavior and Personality: An International Journal, 47(5), e7805. doi: org/10.2224/sbp.7805

Job, V., Dweck, C., S., \& Walton, G., M. (2010). Ego depletion - Is it all in your head? Implicit theories about willpower affect self-regulation. Psychological Science, 21(11), 1686-1693. doi:10.1177/0956797610384745

Kasapoglu, K., \& Didin, M. (2019). Life skills as a predictor of psychological well-being of preservice pre-school teachers in Turkey. International Journal of Contemporary Educational Research, 6(1), 70-85. doi.org/10.33200/ijcer.544232

Kopp, A., \& Jekauc, D. (2018). The influence of emotional intelligence on performance in competitive sports: A Meta-analytical investigation. Sports, 6(4), 175-198. doi:10.3390/ sports6040175

Kurt, N., \& Demirbolat, A.O. (2019). Investigation of the relationship between psychological capital perception, psychological well-being and job satisfaction of teachers. Journal of Education and Learning, 8, 87-99.

Laborde, S., Dosseville, F., \& Allen, M. S. (2016). Emotional intelligence in sport and exercise: A systematic review. Scandinavian Journal of Medicine \& Science in Sports, 26(8), 862-874. doi:10.1111/sms.12510

Liu, W. M., Forbat, L., \& Anderson, K. (2019). Death of a close friend: Short and long-term impacts on physical, psychological and social wellbeing. PLoS ONE, 14(4): e0214838. https://doi.org/ 10.1371/journal.pone.0214838

Magrum, E. D., Waller, S., Campbell, S., \& Schempp, P. G. (2019). Emotional intelligence in sport: A ten-year review (2008-2018). International Journal of Coaching Science, 13(2), 36-51.

Mayer, J. D., Caruso, D. R., Salovey, P. (2016). The ability model of emotional intelligence: Principles and updates. Emotion Review, 8(4), 290-300. doi: 10.1177/1754073916639667 
Malinauskas, R., Dumciene, A. (2017). Psychological wellbeing and self-esteem in students across the transition between secondary school and university: A longitudinal study. Psihologija, 50(1), 21-36.

Malinauskas, R., \& Sniras, S. (2010). Emotional intelligence among future sport pedagogues: Results of an empirical study. Science and Processes of Education, 4(13), 81-88.

Meshkat, M. \& Nejati, R. (2017). Does emotional intelligence depend on gender? A study on undergraduate English majors of three Iranian universities. SAGE Open, 7(3), 1-8. doi:10.1177/2158244017725796.

Moffitt, T. E., Arseneault, L., Belsky, D., Dickson, N., Hancox, R. J., Harrington, H., et al. (2011). A gradient of childhood self-control predicts health, wealth, and public safety. Proceedings of the National Academy of Sciences of the United States of America, 108(7), 2693-2698. doi:10.1073/pnas.1010076108

Montvilaitè, G., \& Antinienè, D. (2019). Emotional intelligence and stress coping strategies of medical residents. Baltic Journal of Sports \& Health Sciences, 4(115), 13-19. doi:10.33607/ bjshs.v4i115.818

Murphy, A., \& Janeke, H. C. (2009). The relationship between thinking styles and emotional intelligence: an exploratory study. South African Journal of Psychology, 39(3), 357-375. doi:10.1177/008124630903900310

Naqvi, I. H., Iqbal, M., \& Akhtar, S. N. (2016). The relationship between emotional intelligence and performance of secondary school teachers. Bulletin of Education and Research, 38(1), 209-224.

Nielsen, K. S., Gwozdz, W., \& De Ridder, D. (2019) Unraveling the relationship between trait selfcontrol and subjective well-being: The mediating role of four self-control strategies. Frontiers in Psychology, 10:706, 1-10. doi:10.3389/fpsyg.2019.00706

Nikbakhsh, R., Nourollahi, H., Mirzaei, A., \& Rahimi, M. (2014). Comparision of emotional intelligence on sport coaches. European Journal of Experimental Biology, 4(3), 98-101.

Pacesova, P., Smela, P., \& Kracek, S. (2019). Personal well-being as part of the quality of life: Is there a difference in the personal well-being of women and men with higher level of anxiety trait regarding their sport activity? Physical Activity Review, 7, 201-208. doi:10.16926/par.2019.07.24

Ryff, C. (1989). Happiness is everything, or is it? Explorations on the meaning of psychological well-being. Journal of Personality and Social Psychology, 57(6), 1069-1081.

Ryff, C., \& Keyes, C. (1995). The structure of psychological well-being revisited. Journal of Personality and Social Psychology, 69(4), 719-727.

Salovey, P., \& Mayer, J. D. (1990). Emotional intelligence. Imagination, Cognition and Personality, 9(3),185-211.

Sánchez-Álvarez, N., Extremera, N., \& Fernández-Berrocal, P. (2016). The relation between emotional intelligence and subjective well-being: A meta-analytic investigation. The Journal of Positive Psychology, 11(3), 276-285. https://doi.org/b86g

Schutte, N. S., Malouff, J. M., Hall, L. E., Haggerty, D. J., Cooper, J. T., Golden, C. J. et al. (1998). Development and validation of a measure of emotional intelligence. Personality and Individual Differences, 25(2), 67-77. 
Sela, A., Berger, J., \& Kim, J. (2017). How self-control shapes the meaning of choice. Journal of Consumer Research, 44(4), 724-737. doi:10.1093/jcr/ucx069

Shahzad, S., \& Bagum, N. (2012). Gender differences in trait emotional intelligence: A comparative study. Business Review, 7(2), 106-112.

Shoda, Y., Mischel, W., \& Peake, P. K. (1990). Predicting adolescent cognitive and selfregulatory competencies from preschool delay of gratification: Identifying diagnostic conditions. Developmental Psychology, 26(6), 978-986. doi:10.1037/0012-1649.26.6.978

Singh, M., \& Sachdev, S. (2020). Correlation between general intelligence, emotional intelligence and stress response after one the month practice of moderate intensity physical exercise. Journal of Exercise Physiology Online, 23(1), 38-47.

Singh, S., \& Sharma, N. R. (2018). Self-regulation as a correlate of psychological well-being. Indian Journal of Health and Well-being, 9(3), 441-444.

Sukys, S., Tilindiene, I., Cesnaitiene, V. J. \& Kreivyte, R. (2019). Does emotional intelligence predict athletes' motivation to participate in sports? Perceptual and Motor Skills, 126(2), 305-322. https:// doi.org/10.1177/0031512518825201

Tangney, J. P., Baumeister, R. F., \& Boone, A. L. (2004). High self-control predicts good adjustment, less pathology, better grades, and interpersonal success. Journal of Personality, 72, 271-324. doi:10.1111/j.0022-3506.2004.00263.x

Trigueros, R., Aguilar-Parra, J., Álvarez, J., González-Bernal, J. J., \& López-Liria, R. (2019). Emotion, psychological well-being and their influence on resilience. A study with semi-professional athletes. International Journal of Environmental Research and Public Health, 16(21), 4192. doi:10.3390/ijerph16214192

Ubago-Jiménez, J. L., González-Valero, G., Puertas-Molero, P., \& Garcia-Martínez, I. (2019). Development of emotional intelligence through physical activity and sport practice: A systematic review. Behavioral Sciences, 9(4), 44. doi:10.3390/bs9040044

Wennerhold, L., \& Friese, M. (2020). Why self-report measures of self-control and inhibition tasks do not substantially correlate. Collabra: Psychology, 6(1), 9. http://doi.org/10.1525/collabra.276

Wijekoon, C. N., Amaratunge, H., Silva, Y., Senanayake, S., Jayawardane, P., \& Senarath, U. (2017). Emotional intelligence and academic performance of medical undergraduates: a cross-sectional study in a selected university in Sri Lanka. BMC Medical Education, 17(1), 176-187. doi: 10.1186/ s12909-017-1018-9

Wolfe, K. (2019). Enhancing the emotional intelligence of students: Helping the critical few. Journal of the Scholarship of Teaching and Learning, 19(3), 16-33. doi:10.14434/josotl.v19i2.23750 


\title{
Žymių sporto pasiekimų turinčių ir jų neturinčių magistrantų emocinè inteligencija, psichologinè gerovè ir savikontrolè
}

\author{
Audronė Dumčienė
}

Lietuvos sporto universitetas, Sporto g. 6, 44221 Kaunas, audrone.dumciene@lsu.lt

\section{Santrauka}

Tyrimo tikslas - atskleisti antrosios studijų pakopos studentų emocinio intelekto, psichologinès gerovės ir savikontrolès ypatumus bei šių konstruktų komponentų tarpusavio sąsajas, pasiūlyti modelius psichologinès gerovės komponentų vertėms prognozuoti. Tyrime naudota Schutte emocinès inteligencijos klausimynas, Ryff psichologinės gerovès vertinimo bei Tangney savikontrolès vertinimo skalès. Tyrime savanoriškai dalyvavo 65 antrosios pakopos studentai: 33 vyrai ir 32 moterys, 14 iš jų turẻjo aukštų sporto pasiekimų. Nustatyta, kad vyrų emocijų suvokimo ir emocijų valdymo įverčiai reikšmingai aukštesni nei moterų. Pasiekusių aukštų rezultatų sporte studentų visų komponentų ịverčiai aukštesni nei nepasižymėjusių sporte, tačiau tik emocijų suvokimo ir emocijų naudojimo komponentų ịverčiai reikšmingai aukštesni. Psichologinès gerovès komponentų îverčių vidurkių skirtumai lyties atžvilgiu buvo statistiškai reikšmingi. Aukštesni šie moterų ịverčiai: meistriškumas aplinkoje, gyvenimo tikslai ir asmeninis tobulejjimas, o vyrų - autonomija bei pozityvūs santykiai. Pasiekusių aukštų sporto rezultatų studentų tik autonomijos komponento įverčių vidurkis reikšmingai aukštesnis nei nepasižymejjusių sporte studentų. Konstrukto savikontrolès komponentų savidisciplinos ir patikimumo įverčiai buvo reikšmingai aukštesni vyrų nei moterų, o komponento neimpulsyvus veikimas aukštesnis moterų nei vyrų. Pasiūlyti modeliai psichologinės gerovès komponentų vertèms prognozuoti.

Esminiai žodžiai: magistrantai, emocine inteligencija, psichologinè gerové, savikontrole, sporto pasiekimai. 